\title{
The Organisation of Anti-Leprosy Measures in Surinam.
}

\author{
P. H. J. Lampe.
}

\section{(Reprinted from \\ Het Geneeskundig Tijdschrift voor Nederlandsch Indie).}

\section{Provisions of THE LAW.}

$\mathrm{E}$ VEN as early as 1728 , it was forbidden for cases of leprosy to make their appearance in public, and since 1763 , infected slaves have been segregated on the estates (Fermin).

The first ordinance was dated from 1790 , and an asylum was erected for infected slaves (at that time a few Europeans were infected on the estates).

After the measures were enacted under which only slaves could be forced into segregation, further measures were taken in the ordinances of 1830,1845 and of 1855 , ordaining that the police could bring before a commission all suspected cases seen on public roads. If those persons were declared to be infected, segregation was ordered in an asylum. Sufferers who voluntarily submitted themselves to an examination could not be forced into segregation, unless they appeared on public roads.

On January lst, 1930, the Royal Warrant of September, 1929 , No. 32 (known as Leprosy-Ordinance, 1929), came into force, cancelling the leprosy-ordinances of 1830,1845 and 1855.

\section{The Leprosy-Ordinance, 1929.}

The leprosy-ordinance of 1929 has altered the regulation of compulsory segregation, which was to be considered as a punishment. Instead of this, medical treatment of nonsegregated patients is placed in the foreground, whereby they have to obey the precautionary measures which are stipulated by the medical authorities with a view to preventing infection. In the event of these stipulations not being carried out or fully complied with, or in case the domestic conditions, considered in connection with the nature and state of the disease, are such that the most necessary stipulations cannot be complied with segregation is ordered at once. The stay in the asylum, where all attention is given to the medical treatment, does not last any longer than is deemed necessary or desirable for medical reasons. The asylum thus gets the character of an institute for treatment, from whence 
the patients can be discharged, when in accordance with the generally accepted views the treatment can be continued at home. The discharge is carefully prepared, in particular with regard to the contemplated place of residence.

The Organisation of Anti-Leprosy Measures, Based ON THE LEPROSY-ORDINANCE OF 1929.

This organisation is looking after :-

I. The tracing of cases of leprosy.

II. The treatment of patients, not segregated in asylums.

III. The control regarding obedience to the provisions stipulated by the medical authorities; and

IV. The segregation of patients in asylums and their treatment there.

\section{I.-The Tracing of Cases of Leprosy.}

Nobody is considered to be suffering from leprosy unless he is certified by a board of medical men, appointed by the Governor for that purpose (Article 5, LeprosyOrdinance). The board, known as "Leprosy Medical Board," consists of five members ; the Surgeon-General is officially a member and chairman. The board is assisted by a physician appointed by the Governor.

\section{(a) Examination of School Children.}

In the City of Paramaribo, the schools are visited by the above physician. He carefully examines the teachers and pupils at least once in every four years, and as often as will be deemed desirable by the SurgeonGeneral, on the understanding that newly-appointed teachers have to be examined before their admission to the school, and newly-registered pupils during the first half-year of their attending the school. The teachers and children who object to submitting to this examination are not allowed to continue attending the school. The Surgeon-General is authorised to appoint another physician for this examination in case such is requested.

In the districts, the district medical officers have the same authority and obligations. As a rule, the schools in the districts are visited four times a year by the district medical officers.

This examination of school children has proved to be the most efficient way of finding out slight or early cases of leprosy. In the beginning -in accordance with a stipulation in the Education-ordinance-children were not permitted to attend the schools unless they could show a testimonial from a private physician (often the family 
doctor) declaring that the children were not suffering from any infectious disease.

In 1927-1928, all school children were thoroughly examined for leprosy by specially-appointed physicians in anticipation of the new leprosy-ordinance. In Paramaribo, where about 8,800 children were examined, the result showed that of the school children who were brought before the Leprosy Medical Board as being suspected cases, 123 were declared infected, and 44 so highly suspicious that they were forbidden to attend the schools ; clearly a proof that the above-mentioned examination must be done by physicians specially appointed for that purpose. This is guaranteed for the future by the Leprosy-ordinance of 1929.

\section{(b) Examination of Relations or Contacts : Voluntary Announcement.}

Besides the means of regular school examinations, some suspected cases are traced by medical examination of relations or contacts of newly-detected leprosy-patients, and by medical examination of those who voluntarily appear before the Board (especially young adults) or of persons brought before the Board by others (servants, nurses, laundresses, etc.). Some cases are also detected in hospitals or dispensaries (for skin diseases).

\section{(c) Compulsory Announcement.}

It may be added that every medical man in Surinam is in duty bound to communicate with the Board as soon as he discovers leprosy in any person or signs which give rise to suspicion of that disease.

\section{II.-The Treatment of Non-Segregated Patients.}

The leprosy-ordinance does not provide for any compulsory treatment. Yet in Surinam people have not refused treatment.

\section{1.-The Treatment in the City of Paramaribo.}

In the City of Paramaribo, a special service takes care of the regular treatment of all non-segregated patients. The chief of this service is assisted by two nurses (routine matters, attending of wounds, house visits). All laboratory examinations are done in the leprosy-laboratory, under supervision of a bacteriologist.

In accordance with the decision of the Leprosy Medical Board, patients are attended either at home or at an outdoor dispensary. 
As a general rule patients who can be recognised as such by any one at first sight and bacteriologically positive cases, are visited and attended at home, whilst all other patients are allowed to visit the dispensary twice a week or as often as is deemed necessary by the physician charged with their treatment. They must not, however, be seen in public for other purposes.

\section{(a) The Treatment at Home.}

The number of patients attended at home in Paramaribo amounts to 45 (October, 1931). This number was larger in the past. The decline is the result of the increase of the number of bacteriologically positive cases as a consequence of a better laboratory technique and the evacuation on a still larger scale of positive cases, the latter in consequence of a more serious view taken by the Leprosy Medical Board and a more severe insistance on obedience to the provisions stipulated.

(b), The Dispensary for Leprosy-Patients.

The dispensary is situated in the grounds of the leprosy laboratory and the meeting room of the Leprosy Medical Board. The number of patients being attended clinically was 249 at the end of October, 1931.

The great difficulty in this dispensary, as with every longlasting mass-treatment, is that with the duration of the treatment, an increasing number of absentees is noticeable. The attendance is about 85 per cent. Only by severe control and by means of punishment (annulment of favourable stipulations) can the attendance be kept to this standard.

\section{(c) The Dispensary School.}

Close to the dispensary for leprosy patients, an open-air school has been built (the type of school with cement floor, wainscot and roof on poles) for infected or suspected school children, who owing to repeated negative results of bacteriological examinations of all kinds, may be attended clinically. It is a Government public school where religious teaching is given to co-religionists by the different Missions. This school for children suffering from leprosy-known under the name of dispensary school-most obviously demonstrates the modern view on leprosy combatment. The school, inaugurated and taken into use on January 19th, 1931, is supplying a much-needed want.

After the mass removal of child victims from the public schools, it was too often proved that that measure alone was not sufficient. Whilst the healthy brothers and sisters 
attended the school, the sick children were occupied with the nursing of young children and babies, assisting in the household (laundry work) and going into shops for foodstuffs and into the market ; uncontrolled children were always on the streets ; many of them did not even sleep at home. Besides, in consequence of their not being allowed to attend the schools many of those children who probably in the future might be able to earn a living, remained without any elementary education. A great advantage of the dispensary school is that treatment can take place there more regularly and in quieter and easier circumstances. The children are now going, under the supervision of the teacher of the class, to the dispensary for treatment. Further, more attention can be paid to the neatness of their garments and the cleanliness of their bodies, whilst the dispensary school also gives an opportunity to call the children's attention to the hygienic stipulations, which must be regarded of high value in connection with their illness.

The number of children attending the dispensary school is varying. There are children admitted (newly traced cases which became negative) and there are children falling off who are no longer suspected, and who are going to the ordinary schools, cases which became positive are staying at home or are evacuated. At the end of October, 1931, the number of children registered was 167. During the year 1931, up to the end of October, 185 children were registered at the dispensary school. During the same period, 18 children left the school, viz., four owing to their being allowed to attend the ordinary school again, eleven owing to positive results of the bacteriological examination (all of them being removed to an asylum) and three owing to bad conduct (house arrest). The number of school absentees is less than that of any public school in Paramaribo.

The number of teachers is four. These teachers are receiving a bonus besides their salary. They have a dressing and disinfecting room in the dispensary school.

\section{(d) The Playground of the Dispensary School.}

An extensive playground, situated around the dispensary school, was taken into use on August 18th, 1931. The ground is enriched with swings, seesaws, rings, climbing ropes, springboards, goals, baskets for basket-ball, etc. The idea is to pay close attention to well-taught body exercises, gymnastics, marching, mass-games, etc. A great therapeutic effect is expected from well-taught body exercises. 


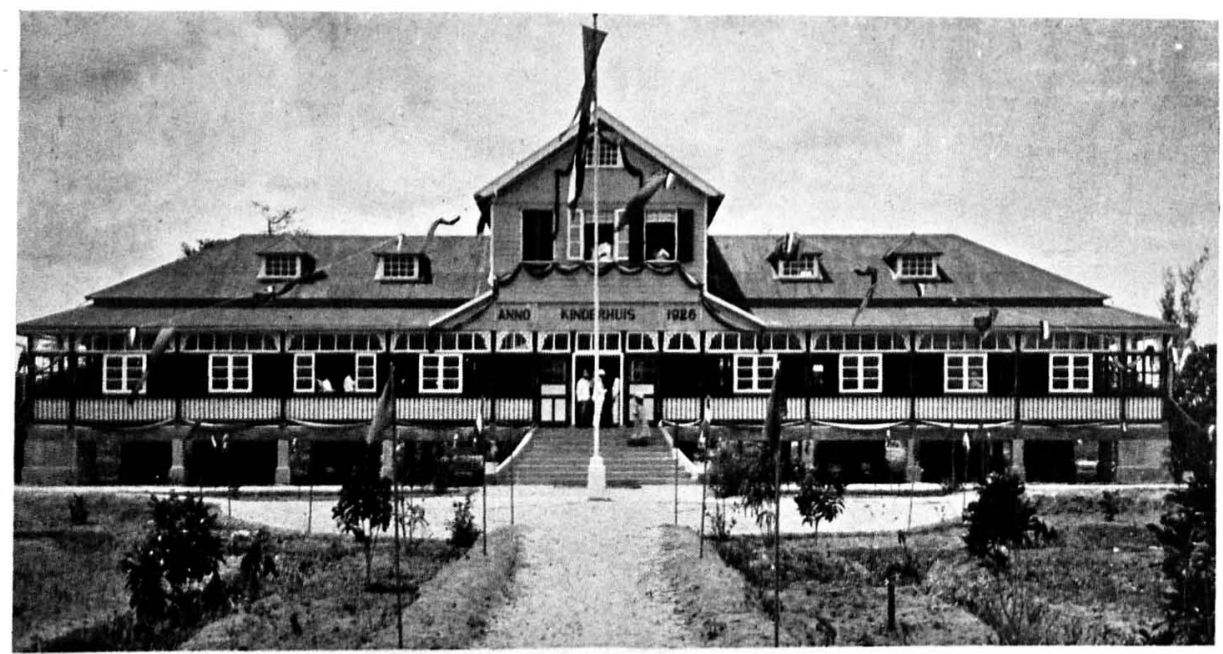

1

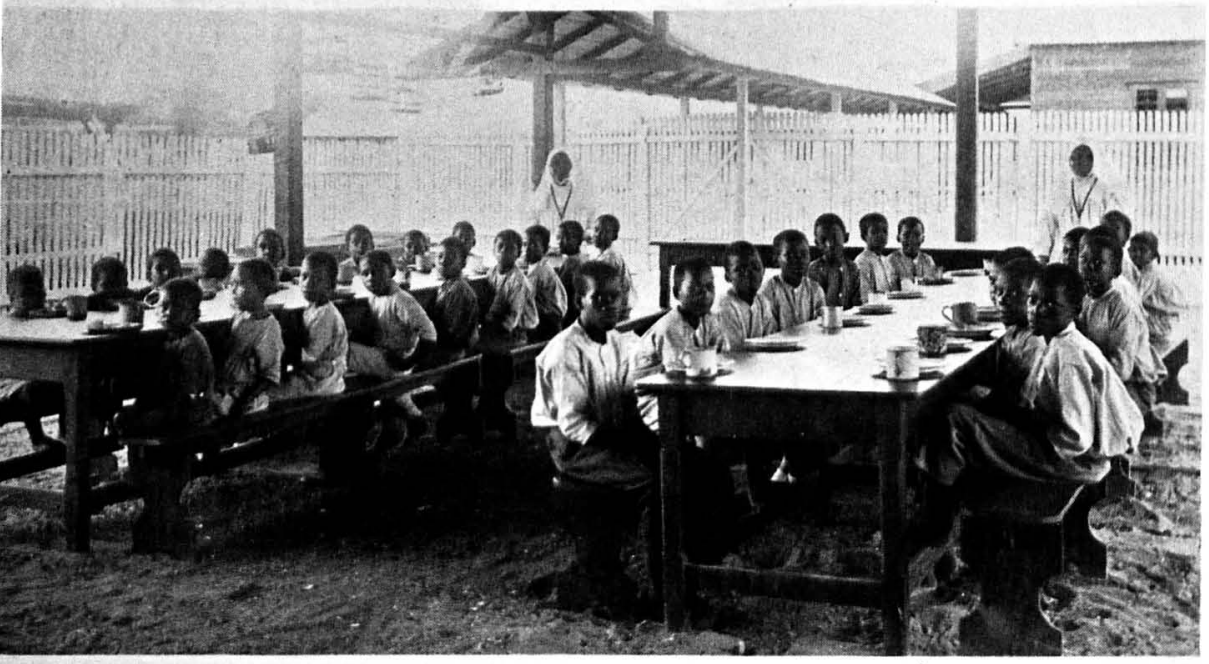

2

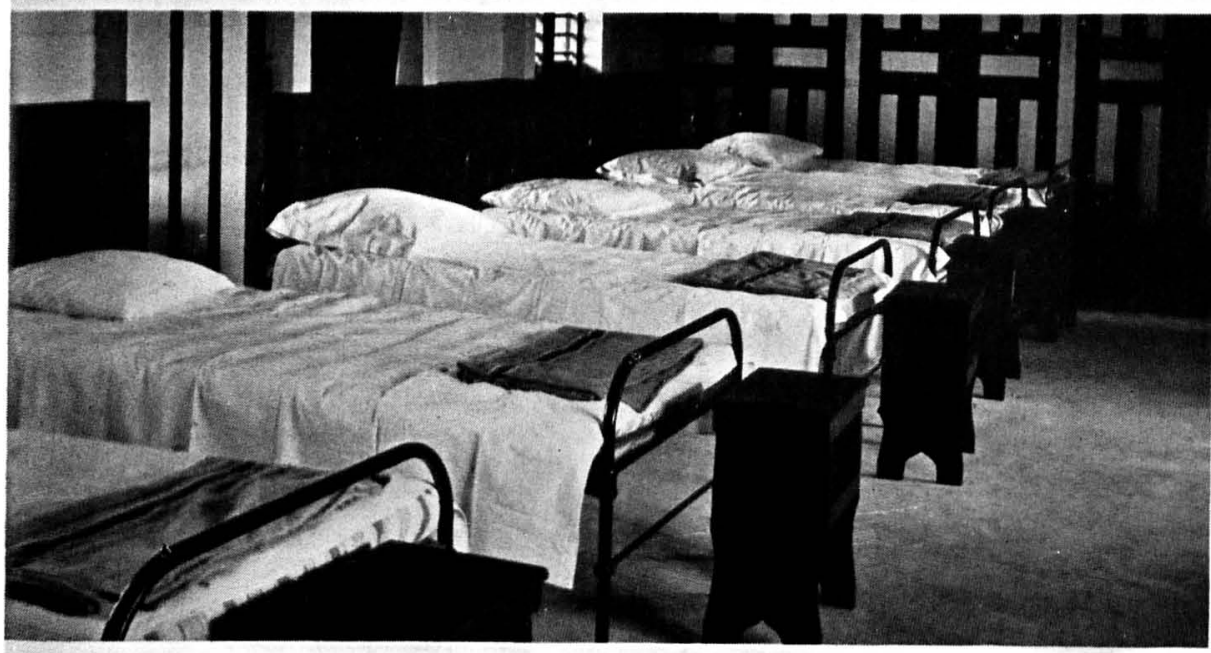

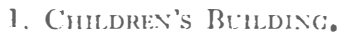

2. BoYs' QLARTLRS.

i. BEIJRUU. 


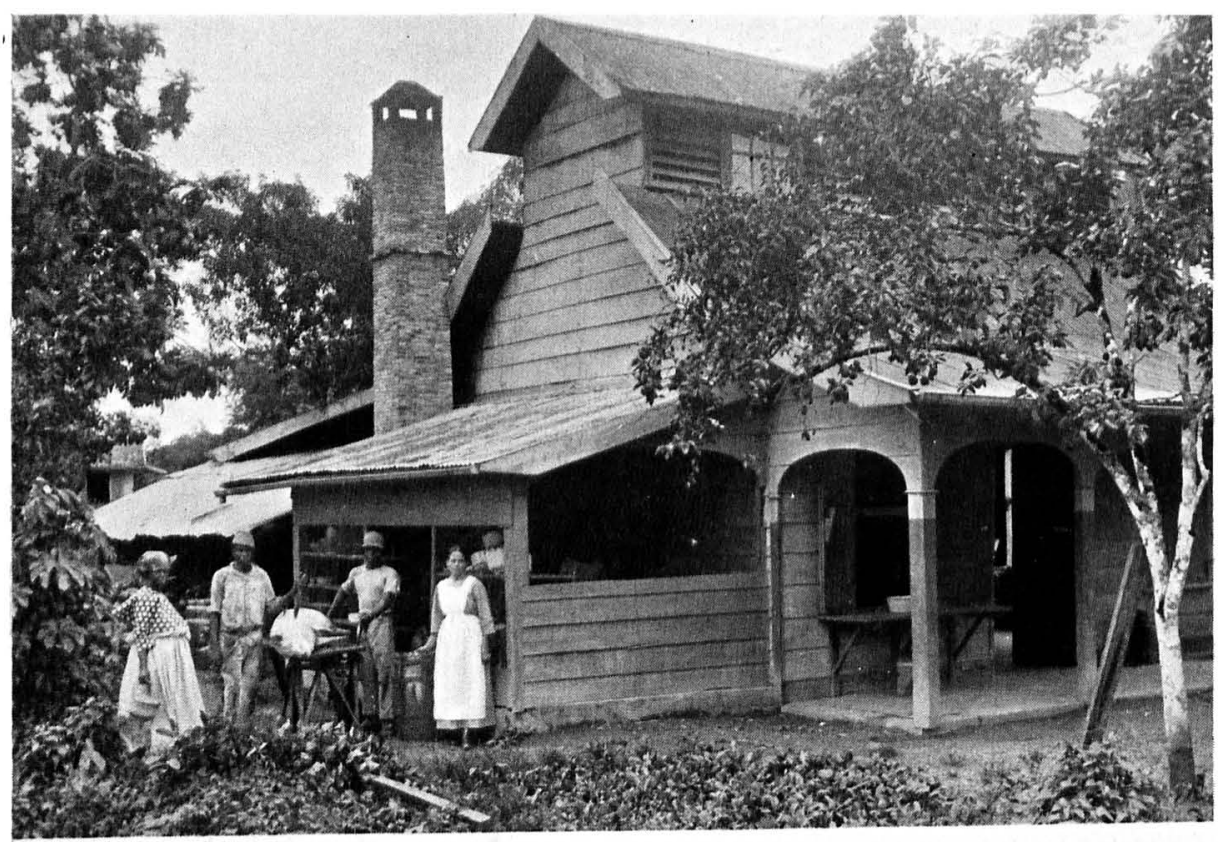

1

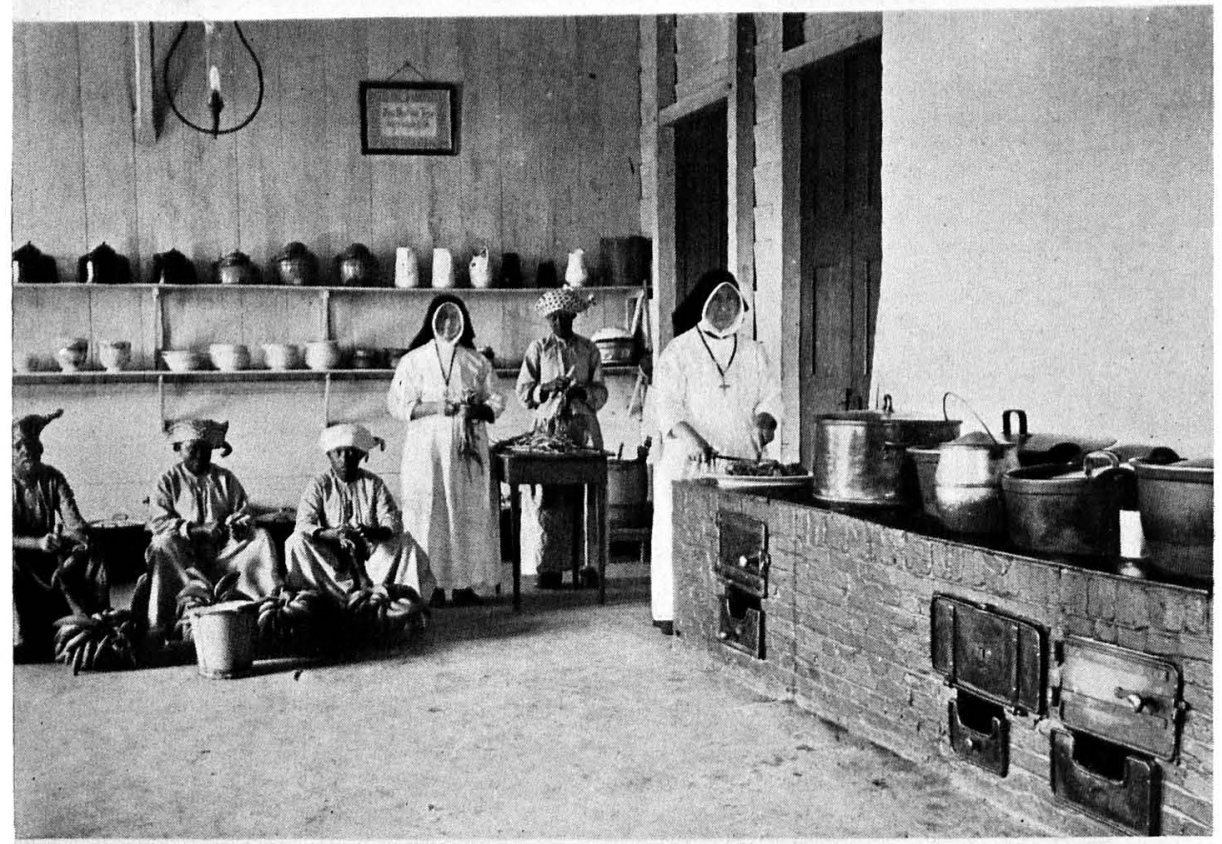

2

1. "Bethrsda" Leprosy Asylum. Kitchen.

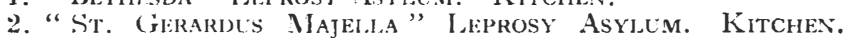


(e) The Surinam Leprosy Relief Association.

The Surinam Leprosy Relief Association is a private association which has set itself the task of combating the endemic disease of leprosy in Surinam. On June 29th, 1931, the Governor sanctioned the regulations. Large donations, the proceeds of a film-performance and a lecture on " Leprosy," contributions, etc., made it possible this year to start supplying food to the children visiting the dispensary school.

This supplying of food free of cost to school children is not to be considered as a social measure only. It is hoped that by means of good nourishment, improvement of general health conditions and of the resistance of the patients, the symptoms which have manifested themselves will subside.

Other important advantages of the food supply are the decrease of school absentees and the possibility of keeping the children under control and care much longer. On the one side more attention can then be paid to well-taught body exercises and to the care of the skin (regular bathing, treatment of the skin with ointment of chaulmoogra oil and chaulmoogra soap). On the other hand the children are remaining longer off the streets and yards and longer from their home circle. The idea is to keep the children so long under care (lunch at school), that on their arrival at home, the younger ones especially, are so weary that they go to bed directly.

\section{2.--The Treatment in the Districts.}

In the districts leprosy patients are attended by the district medical officers. These physicians are also looking after the obedience to the obligations imposed on the patients by the Leprosy Medical Board.

\section{III.-Control on Obedience to the Provisions \\ Stipulated by the Leprosy Medical Board.}

The principle of the Leprosy-ordinance of 1929 is, that a chance must be given to every patient to prove himself willing to obey the necessary provisions, stipulated by the Leprosy Medical Board; in the case of these provisions being obeyed, no segregation in an asylum is ordered. Only if it is clear that the most elementary provisions cannot be obeyed, and if cases are regarded as highly infectious, is removal to an asylum ordered at once. 
The provisions stipulated for each case in particular are indicated to the patients or to the parents or to representatives by word of mouth and by letter.

Some of the most frequent stipulations which must be obeyed are :-

(a) In bacteriologically positive cases :-

1. Segregation in an isolated house, to be approved of by the Leprosy Medical Board; as a rule, one or two adults are allowed to join the patient as supporters.

2. Prohibition to carry on a trade (seamstresses, embroiderers, laundresses, tailors, manufacturers of sweets, etc.).

3. Removal of the children on the illness of a grownup or removal of the healthy children in case of illness of a child.

4. Prohibition to receive visits, or visits of children.

5. The hedging of the yard, in case it is in open contact with other yards.

(b) In bacteriologically negative cases :-

1. Prohibition to appear in public, except for the visits to the dispensary.

2. Prohibition to visit public places (clubs, dances, theatres).

3. Prohibition to carry on a trade.

4. Removal of young children.

(c) Less severe provisions are stipulated for the so-called "late neural types"; they are allowed to appear in public freely, remaining under control of the service.

The physician, charged with the treatment of nonsegregated patients and the nurses charged with house visits see that the provisions are obeyed. In the districts, the district medical officers have control. The control is facilitated by a certa $n$ amount of supervision on the part of the population itself. They have a better realisation that obedience to the regulations on the part of non-segregated patients decreases the danger of infection. The practice has proved that the provisions are being obeyed fairly well not because of conviction but because of fear. Owing to negligence, 26 patients were removed to an asylum in 1930 , and 19 patients up to the end of October, 1931.

\section{IV.-Segregation of Patients Suffering from Leprosy IN AsYlums aNd TheIR TREATMENT.}

Physicians are under supervision of the Surgeon-General on account of the Government superintending the treatment of all sufferers from leprosy, all doubtful cases and all 
asylums for their treatment (Article 1, Leprosy-Ordinance). The newly-appointed leprologist is charged with the supervision of the asylums.

A change in the nature or type of the segregated cases of leprosy makes a more " medical " character of the supervision in the asylums more desirable and useful now than ever before.

Formerly, in the time of the compulsory segregation of sufferers who were seen on public roads, the greater part of those segregated cases consisted generally of aged invalids and social impossibles, on the one hand those cast out from their own circle (especially men who could not make themselves useful any longer); on the other hand, victims of the more serious attention of the police, more of ten arrested on account of animosity. Many of themto be classified as "late neural types"-do not belong to an asylum for medical reasons.

Besides that category of patients, more of ten segregated because of social reasons, a new element made its entry in later years, viz., the cases to be regarded as highly infectious, especially young sufferers and children, of ten not to be recognised as cases of leprosy without a thorough medical examination.

In consequence of the new ordinance, the number of isolated patients has not remained constant or decreased; on the contrary, the population of the asylums has highly increased since the activities, based on the new leprosy ordinances (see statement below).

\begin{tabular}{|c|c|c|c|c|c|c|}
\hline & Year. & & Gr. Chatl. & Ger. Majella. & Bethesda. & Total. \\
\hline $\begin{array}{c}\text { Dec., } \\
", \\
" \\
" \\
" \\
" \\
" \\
" \\
" \\
\text { ", } \\
\text { July, } \\
\text { Aug., } \\
\text { Sept., } \\
\text { Oct., }\end{array}$ & $\begin{array}{l}1920 \\
1921 \\
1922 \\
1923 \\
1924 \\
1925 \\
1926 \\
1927 \\
1928 \\
1929 \\
1930 \\
1931 \\
1931 \\
1931 \\
1931\end{array}$ & $\begin{array}{l}\ldots \\
\ldots \\
\ldots \\
\ldots \\
\ldots \\
\ldots \\
\ldots \\
\ldots \\
\ldots \\
\ldots\end{array}$ & $\begin{array}{l}145 \\
135 \\
136 \\
144 \\
151 \\
154 \\
167 \\
161 \\
166 \\
165 \\
158 * \\
158 \\
153 \\
157 \\
177\end{array}$ & $\begin{array}{l}123 \\
123 \\
131 \\
119 \\
117 \\
110 \\
139 \\
157 \\
176 \\
168 \\
194 \\
207 \\
210 \\
216 \\
215\end{array}$ & $\begin{array}{l}56 \\
55 \\
57 \\
61 \\
61 \\
57 \\
49 \\
52 \\
66 \\
74 \\
87 \\
88 \\
90 \\
91 \\
90\end{array}$ & $\begin{array}{l}324 \\
313 \\
324 \\
324 \\
329 \\
321 \\
355 \\
370 \\
408 \\
407 \\
439 \\
453 \\
553 \\
464 \\
482\end{array}$ \\
\hline
\end{tabular}

Add 30 Javanese cases who were evacuated to their native country at the end of 1930 . 
To make it clearer, it may be stated that the population of Surinam amounts to 134,000 souls, of which 47,000 are in the City of Paramaribo. For information about the appearance of leprosy in Surinam, i.e., in the various races and ages, see the article "Lepra in Suriname" (Leprosy in Surinam), Ned. Tijdschirft voor Geneeskunde, 1929, II, No. 43, pp. 4903-4915 (Tropical Diseases Bulletin, 1930, August, Vol. 27, No. 8, pp. 672).

The increase in the number of children segregated in asylums is remarkable for the period 1928-1931. Both of the two private asylums are now in possession of separate wards for children; Bethesda since September, 1926 ; St. Gerardus Majella, since August, 1931.

\section{Expenditure of the Service.}

The expenditure of the service so far as a charge upon the Colonial estimates, amounts to about F240,000 per annum, that is, $\mathrm{Fl} \cdot 80$ per head of the population.

Survey of the Decisions of the Leprosy Medical Board.

(Based on the Leprosy-Ordinance, 1929.)

\begin{tabular}{|c|c|c|c|c|}
\hline \multirow{2}{*}{ Leprosy Medical Board. } & \multicolumn{2}{|c|}{1930.} & \multicolumn{2}{|c|}{ Fan. to Oct., 1931.} \\
\hline & Children. & Grown-ups. & Children. & Grown-ups. \\
\hline $\begin{array}{ll}\text { Declared infected.. } & \ldots \\
\text { Declared suspected } & \ldots \\
\text { Under supervision } & \ldots \\
\text { No leprosy } & \text {.. }\end{array}$ & $\begin{array}{r}72 \\
77 \\
113 \\
33\end{array}$ & $\begin{array}{r}153 \\
33 \\
49 \\
18\end{array}$ & $\begin{array}{l}42 \\
24 \\
84 \\
34\end{array}$ & $\begin{array}{r}108 \\
13 \\
30 \\
6\end{array}$ \\
\hline $\begin{array}{l}\text { Evacuated to an asylum .. } \\
\text { Compulsory removal to } \\
\text { isolated homes.. } \\
\text { Prohibited to carry on a } \\
\text { trade . } \\
\begin{array}{l}\text { Clearing of yard-houses } \\
\text { Removal of children }\end{array}\end{array}$ & $\begin{array}{l}37 \\
- \\
- \\
-\end{array}$ & $\begin{array}{l}83 \\
- \\
- \\
-\end{array}$ & $\begin{array}{r}26 \\
3 \\
- \\
-\end{array}$ & $\begin{array}{r}59 \\
9 \\
9 \\
7 \\
6 \\
8\end{array}$ \\
\hline $\begin{array}{l}\text { Prohibited to attend the } \\
\text { ordinary schools } \\
\text { Allowed again to attend the } \\
\text { ordinary schools }\end{array}$ & $\begin{array}{l}49 \\
12\end{array}$ & - & $\begin{array}{r}35 \\
4\end{array}$ & - \\
\hline $\begin{array}{l}\text { Admitted into society with } \\
\text { further treatment } \\
\text { Discharged from an asylum }\end{array}$ & $\begin{array}{r}12 \\
2\end{array}$ & 17 & $\frac{4}{-}$ & $\begin{array}{l}2 \\
3\end{array}$ \\
\hline
\end{tabular}

N.B.-Many patients appear several times before the Board in the course of a year. The sittings of the Board are arranged by the physician charged with the treatment of non-segregated patients (historia morbi) and by the leprologist (bacteriological examinations). 
Survey of the Number of Patients under Treatment and Supervision OF THE SERVICE.

\begin{tabular}{|c|c|c|c|c|c|}
\hline Cases Known. & $\begin{array}{l}\text { Dec., } \\
1927 .\end{array}$ & $\begin{array}{l}D_{e c_{.}} \\
1928 .\end{array}$ & $\begin{array}{l}\text { Dec., } \\
1929 .\end{array}$ & $\begin{array}{l}\text { Dec., } \\
1930 .\end{array}$ & $\begin{array}{l}\text { Oct., } \\
1931 .\end{array}$ \\
\hline 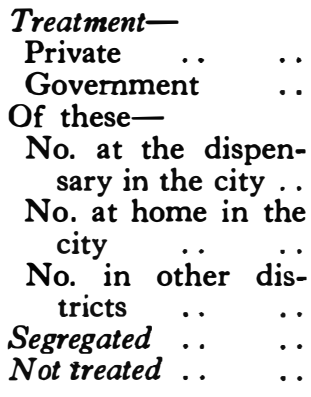 & $\begin{array}{r}4 \\
11 \\
? \\
370 \\
?\end{array}$ & $\begin{array}{r}35 ? \\
444 \\
244 \\
87 \\
113 \\
408 \\
?\end{array}$ & $\begin{array}{r}21 \\
513 \\
\\
327 \\
\\
85 \\
\\
101 \\
407 \\
50\end{array}$ & $\begin{array}{r}350 \\
80 \\
\\
127 \\
439 \\
54\end{array}$ & $\begin{array}{r}45 \\
151 \\
482 \\
171\end{array}$ \\
\hline $\begin{array}{rrr} & \text { Total } & \ldots \\
\text { Others } & \text { under super- } \\
\text { vision } & \ldots & \ldots\end{array}$ & 435 & 807 & $\begin{array}{l}991 \\
317\end{array}$ & $\begin{array}{r}1,072 \\
419\end{array}$ & $\begin{array}{r}1,107 \\
200\end{array}$ \\
\hline
\end{tabular}

\section{Summary.}

The standpoint of the First and Second International Leprosy Conference that "compulsory segregation in asylums is the only means to combat leprosy," is nowadays practically forsaken. Even in those countries where the cases of leprosy are cast out, only segregation of those in a very advanced state can be attained, with which the combatting of the disease is little relieved.

"Any drastic measures leading to extensive hiding of early cases, are likely to do more harm than good " (Sir Leonard Rogers). This also concerns, unless there are very particular circumstances, the compulsory segregation for medical reasons, nowadays put into practice in Surinam.

The following circumstances are, however, met with in Surinam, viz. :-

1. Surinam has a small area and a small number of inhabitants.

2. The population is registered (compulsory notification of births, deaths, removals).

3 . The children are obliged to attend a school (compulsory attendance).

4. The new ordinance- on which the compulsory segregation for medical reasons is based - has been prepared by means of an intensive leprosy-campaign (propaganda, tracing of cases of leprosy) whereby not one disagreeable measure was used.

Under present conditions, it seems to me that the above mentioned mode of combating leprosy is the most efficient 
for Surinam and the most promising for the future, provided that the leader of the service never forgets that the tracing of early cases must be the main object of the organisation ; that segregation in an asylum must not be ordered unless absolutely necessary and in accordance with a defined indication, and also that in the eye of the population, the asylums must have the character of institutions for treatment where the "patients" are not kept longer than is strictly necessary. 